\title{
PROFILED MUSICAL EDUCATION IN THE REPUBLIC OF BELARUS
}

\section{SUMMARY}

Introduction. The article reviews a modernisation problem of pre-university musical education by implementing professional education at a senior level of schools of general education with music specialisation.

Aim of the Study. To illustrate the efficiency of implementation of professional training in preuniversity musical education in the Republic of Belarus and to justify the great demand for specialized musical training in the person-oriented educational system under its present-day development stage.

Materials and Methods. Theoretical analyses of pedagogical literature and and different educational theories. The method of the study is examining existing situation.

Results. Process of individualisation of the profiled education that bases on principles of variation and personification of individual educational strategy of participants has been reviewed. Results of an experiment on implementing profiled musical education are analysed, productivity of interactivity between profiled musical class and the respective university faculty is determined.

Conclusions. Profiled musical education is the optimum base for ensuring the pre-emptive character of pre-university musical education. It forms background for intentional choice by the pupil of the future professional activities and facilitates the future successful socialisation.

Key words: profiled musical education, variety of education, pre-emptive character of education, individualisation of education, individual educational trajectory, participant's individual-creative potential

\section{INTRODUCTION}

Actual tendencies of musical education in the Republic of Belarus have been determined, in relation to emerging labour market, it has been found that pre-university education seeks to enter a more advanced level in respect of higher education level.

At present, the musical education of the Republic of Belarus has the following interrelated tendencies become topical:

1) society's age requirements towards quality of specialist training;

2) innovations in structure and contents of higher education;

3) modernisation of pre-university education.

Society's age requirements towards professional's level are related to the tight competition in the labour market. Innovations in the structure of higher musical education have been caused by the necessity of balance between state expenses for preparation of specialists and individual resources of a student - the future teacher within the field of musical education. Differentiation in the flow of graduates for a full term and shorter terms of education has presently become a norm for universities of the Republic of Belarus that ensure musical-pedagogical training of students. Graduates with pre-university training that corresponds to the scope of a college are entitled to 
study at the university for a period of three years, graduates of schools (gymnasiums) are entitled only to a five-year training.

Innovations to the contents of higher musical education are directed at: a) maintaining social protection of the university graduate through implementation of secondary (additional) specialities and specialization and b) increasing the share of independent creative activity and reducing the share of students' reproductive activity (age range of independent controlled work).

As a result of these findings we conclude that modernisation of pre-university education becomes inevitable.

\section{AIM OF THE STUDY}

To illustrate the efficiency of implementation of professional training in pre-university musical education in the Republic of Belarus and to justify the great demand for specialized musical training in the person-oriented educational system under its present-day development stage.

\section{MATERIALS AND METHODS}

The pre-university stage of music education of the future specialists has always been one of most significant precondition for an effective training at the university. Peculiarity of musical education being related to psycho-motorics and based on the pupil's age and individual qualities need meticulous observance of such pedagogical principles as continuity, system and succession. However, practice of the pre-university music education in the Republic of Belarus indicates that issues of quality implementation of listed pedagogical principles are left open.

One of aspects of this problem is related to the fact that pedagogical training institutions / colleges due to their low ability of competition in the labour market during the previous years have significantly decreased graduation of specialists. This has resulted in an increased number of students with pre-university training at schools entering music-pedagogical faculties (departments) of universities of the Republic of Belarus. Thus, for example, during the previous five years, the rate of students who have entered music-pedagogic faculty of Maxim Tank Belarus State Pedagogical University (hereinafter - BSPU) has grown from 9\% in 2003 to 50\% in 2008. For a comparison, the number of graduates from pedagogic institutes of education, who have entered music-pedagogy faculty of BSPU decreased from $32 \%$ in 2001 to $6.5 \%$ in 2008 .

In such a manner the tendencies of moving the pre-university music education from the "territory" of secondary special education to the "territory" of secondary general education become clear. We should also note one characteristic trait for modern pre-university music education: it became more variable. At present, pre-university secondary general education of a future musician may be offered by a school (state or private), grammar school, lycee, educational complex, and also individual work with a teacher.

In pedagogic researches undertaken during the previous years, the problem of transferring the pre-university education to an advanced level in comparison of the university level of is actively discussed and it fully refers to musical education. The present tendency according to researchers is related to the increase of infomatisation generally in society. Let us add that the amount of information to be absorbed by the future graduate does not fully guarantee the quality of results of his intellectual sphere. The advanced character of pre-university music education assumes a development of the future students' creative and reflexive skills, abilities to gather, perceive and process information, skills to generalise and summarise material, abilities of verbal presentation of presentations to be performed, experiences of concert-performance activities and the like.

Such a situation needs seeking new forms and new contents of pre-university music education. 
Global long-term experience of the general secondary education indicates that profilisation of education can solve this problem in a more efficient way. Process of implementing the profiled musical education should be purposefully focussed on the following common tendencies:

1) approximately $70 \%$ of pupils around the world nowadays receive profiled education (Рыжаков, 2003);

2) a general increase in the amount of those who want to receive a profiled education is observed;

3) aim of the profiled education - ensuring successful socialisation of senior students - the future specialists through recognition and adequate choice of professional activity with a priority of individual development of each of the participants;

4) basis of successful socialisation of future participants of the society through professional activity lies in the conditions of profiled education with the help of variable contents and its implementation in the participant's individual education trajectory;

5) model of profiling in each country has its own specifics related to educational traditions, mentality, national peculiarities and the like (Паздников, 2008).

It is clear that individualisation of education is the principal direction in modern educational system which moves away from the traditional (on knowledge based) paradigms to the direction of education directed at personality. Individualisation of profiling education process is put into practice by implementing selectivity, variability and alternatives, personification of individual educational strategy for each participant.

Historically existing dynamics of the problem of individualisation education move from simple accounting of children's qualities to a careful attitude towards their individual results, and further on - from forming socially demanded personality of the future professional to development of all spheres of his creative individuality.

As it can be noticed, already in the education system of J. А. Komenski (Я. А. Коменский), the need of accounting of pupils' individual qualities has been clearly indicated (Коменский, 1939). I. Е. Unt (И. Э. Унт) speaks within the context of studying individualisation of education that modern system of education must provide possibilities for teacher's creative work "estimated on the basis of accounting, preservation, forming and development of individual pupils" (Унт, 1990).

A significant factor of effective individualisation of education is the circumstance where development management of individual-creative potential can be directed through introduction of a respective set of methods and means. Experiment on implementing the profiled musical education (Гончарова, 2007) showed that conditions of a profiled class on the senior level of a school of general education are the best. Let us note that productivity of functioning of a profiled class depends on interaction of schools and the respective university faculty (department) that provides conformity of educational space of both sides, and likewise integrity of contents of the profiled education.

Development of the participant's individuality in conditions of profiled musical class will be successful if the contents of education is based on principles of humanisation, ergonomics, interdisciplinary integration, problematics, systematics, and succession. Development of a pupil's individuality in profiled music class is possible in case of implementing the following positions:

- presence of qualified staff for teaching profiled disciplines;

- corresponding material basis;

- flexible system of financing and differentiation of payment for teachers' job and university lecturers who work at the profiled class; 
- quality pre-profiled preparation of the participants at the expense of invariable and variable components of education plan.

System of pre-profiled preparation of participants allows to develop their individual potential in a profiled class according to the following directions: a) actualisation of interest towards various types of activities; b) development of common special skills; c) forming of new socially useful values; d) priority implementation of individual forms and methods of education; e) improvement of abilities and skills of self-preparation, self-education, self-training.

Table 1. Educational plan of profiled musical class

\begin{tabular}{|c|c|c|c|}
\hline \multirow[t]{2}{*}{ Training courses, subjects } & \multicolumn{2}{|c|}{$\begin{array}{c}\text { Number of hours in classes } \\
\text { per week }\end{array}$} & \multirow[t]{2}{*}{ Total } \\
\hline & 11 & 12 & \\
\hline \multicolumn{4}{|l|}{ State general education component } \\
\hline Belarusian Language & $2(0)$ & $2(0)$ & $4(0)$ \\
\hline Russian Language & $0(2)$ & $0(2)$ & $0(4)$ \\
\hline Literature & 3 & 3 & 6 \\
\hline Foreign Language & 2 & 2 & 4 \\
\hline Math & 3 & 3 & 6 \\
\hline Physics. Astronomy & 1 & 2 & 3 \\
\hline Chemistry & 1 & 1 & 2 \\
\hline Biology & 1 & 1 & 2 \\
\hline Geography & 1 & 0 & 1 \\
\hline History (World History. History of Belarus) & 2 & 2 & 4 \\
\hline Man. Society. State & 1 & 1 & 2 \\
\hline Physical Training and Health & 3 & 3 & 6 \\
\hline Pre-induction and medical training & 1 & 1 & 2 \\
\hline \multicolumn{4}{|l|}{ State profile component } \\
\hline Special instrument & 2 & 2 & 4 \\
\hline Solfeggio & 1 & 1 & 2 \\
\hline Music Literature & 1 & 1 & 2 \\
\hline Additional instrument / concertmaster class & 1 & 1 & 2 \\
\hline Conducting & 1 & 1 & 2 \\
\hline Vocal & 1 & 1 & 2 \\
\hline World Art Culture & 1 & 1 & 2 \\
\hline Psychological-pedagogical practice & 1 & 1 & 2 \\
\hline Total & 30 & 30 & 60 \\
\hline Component of institutional education & 7 & 7 & 14 \\
\hline Individual component & 3 & 3 & 6 \\
\hline \multicolumn{4}{|l|}{ Modern Music } \\
\hline \multicolumn{4}{|l|}{ Improvisation and Composition } \\
\hline \multicolumn{4}{|l|}{ Basis of Information Technology } \\
\hline \multicolumn{4}{|l|}{ Foreign Language } \\
\hline \multicolumn{4}{|l|}{ Dramatic Creation } \\
\hline \multicolumn{4}{|l|}{ Folklore } \\
\hline Total number of hours that are financed by the budget & 40 & 40 & 80 \\
\hline
\end{tabular}


Introduction of profiled musical education in Belarusian schools started from 2003. Development of educational plan of profiled musical class was based on possibility to implement an individual character of training (Паздников, Гончарова, 2004). Obligatory state component was foreseen in the project of the educational plan that in case of waiver of training in profiled musical class (for example, due to health or decrease in interests towards the given profile) allowed the participant to easily move to a non-profiled (general class) and to continue training according to a uniform educational plan that does not have a profiled component.

Let us note that the profiled component of the educational plan provides for a duty of a participant of a profiled musical class to be present at all his subjects. Individual component of the educational plan ensures variety of training through building up individual educational trajectory of participants and must contain a specific amount of subjects that allow the participant to make choice of discipline in correspondence with individual wishes, interests and possibilities. Individual component of the educational plan allows strengthening learning of one or the other subject of the profiled component on the basis of the participant's choice, specify the perspective of a second (additional) speciality. Let us note the possibility to flexibly correct the contents of individual component of educational plan (in contradiction to the profiled or state component that are obligatory) in correspondence with the changing demands of the society or introduction of new secondary (additional) specialities or specialisations in the learning process of the corresponding faculty of the university.

Pupil's individuality develops in the process, to be more precise - in learning process. Pupil's any activity will be the more productive, the more it is acknowledged, based on voluntary basis, and not on compulsion. In order to acknowledge one's activities, participants must represent the aim, sense and plan of activities. In profiled education, the sense, aim and plan of activities are orientated on the profession. A pupil's choice of musical profile, partially dictated by a seven to nine year interaction with music, signifies perception of the goal of studies - acquisition of the corresponding profession, the meaning of training arises from the goal - to enter and efficiently study at the university - and a plan of activity.

Let us review more closely the plan of learning activity. Structure of the educational plan allows the participant of a profiled musical class to independently:

- choose subjects of individual component of the educational plan;

- determine terms of learning one or the other subject of the individual component (half a year to two years);

- make decision on the tempo of studying the contents of the subject;

- determine the depth of "immersion" into the material to be mastered;

- control interim results (due to lack of severe reporting form in the individual component of educational plan).

Thus reflection and acknowledgement of independent steps in the process of profiled education enable future emerging of analogous skills in deciding professional and life task. Reflection can be enabled in the following ways: at the end of learning week, quarter, half-year of an academic year, participants are offered special lessons where they provide their own marks for their work. On the basis of the pupil's reflexive judgements, the teacher likewise prepares a written mark for his activities. Reflection includes the following positions:

- acknowledgment of the educational task (what is the result of the task and what should be done in order to solve it?); 
- acknowledgment of the aim of the learning activity (what has been done today, what has been reached today, that is, evaluation by the participants themselves of activity results depending on implementation of their goals);

- evaluation of activity methods by the participant (invariable and exclusive), clarification of common methods of activities, skills to separate the common in fulfilling various tasks, awareness of specific activities that are necessary for fulfilment of the task (Гребенюк, 2000).

Let us note that the musical profile is orientated on stability and integrity of learning activities, on absence of obligation to learn, on upbringing love towards work that favourably affect the perfecting of the pupil's individual creative potential. Efficiency of musical profiling as a method to develop individualities of the future graduate is ensured by a high level of study motivation. Not only the goal, sense and plan of the learning activity ensure strengthening the participant's motivation, but also educational contents that foresees all components of entering exam in music at the respective faculty of the university in the profiled and individual components of the educational plan. Stability and integrity of musical profiled education is ensured by the following factors:

1. State component of the educational plan allows ensuring the quality level of preparation for entry tasks in general educational subjects (language, history of Belarus) during two years of studies in a profiled class and stimulates increase of general intellectual level of the participants (in contradiction to music school, music college graduates who have a break in learning general educational disciplines not less than two to three years at the moment of entering the university). Operational experience of the experimental profiled musical class (on the basis of Grammar School No 17 of Moscow) witnesses that all 100\% of the graduates in 2005 entered universities (Гончарова, 2007).

2. Contents of study programs is prepared taking into consideration the participant's individual skills and integrated in the respective programs of the university. Study programs are based on principles of continuity and succession, variability and alternatives, availability, continuation of the individual approach.

3. Obligatory participation in the learning-upbringing process of professorial-teacher composition of the university that directly effectuate not only the study process but also regular diagnostics of the quality of the acquired knowledge.

Integrity of the profiled musical education is ensured by the contents of learning activities that include need, motive, aim, learning activity, self-control, and self-evaluation. A. Hutorsky (A. B. Хуторской) is of the opinion that besides learning activity, it is necessary to review the participant's individual qualities and his educational production (Хуторской, 2005) as these positions are most convenient for diagnostics. The level of development of the participant's individual qualities is determined based on comparison of results of diagnostics in the beginning and the end of the academic year. Furthermore observation, testing, and interview methods can be used.

Learning activity in the context of types of its orientation was reviewed by P. Galperin (П. Я. Гальперин):

1) a full system of instructions, that is, detailed mechanism of activities for the participant, is provided;

2) a ready-made incomplete system of instructions and orientation is provided;

3) a general orientation is provided and it requires that the participant independently prepares an algorithm in every specific case (Гальперин, 1966). 
Let us give a sample of algorithm:

- separate (select) some data, conditions, reasons, facts;

- relate (compare) and group them;

- reconsider, re-phrase, re-formulate the task;

- modify the situation for determining the end result (Гребенюк, 2000).

Efficiency of the profiled musical educational space depends on the list of activities to be carried out by the pupil; the list may include the following:

1) checking contents of the source material (style, époque, genre specifics, author's property, texture, testing conditions and the like);

2) processing a source material (playing in various variants, singing, declamation poetic texts, listening to audio and watching video records, comparing the characteristics, the existing interpretations and so on);

3) independent construction of material (interpretation, arrangement, improvisation, composition and so on).

Content variety of the profiled education of the future pedagogue-musician can ensure an advanced character of pre-university preparation by efficient development of the pupil's musical skills. In our experiment (Гончарова, 2007), during lessons of concert-master class, a system of original tasks was used that helped to bring to light the musicality of the participant according to the following indicators:

1) maturity of elemental musical abilities (ear for music, sense of rhythm, modal sense and the like), that is, abilities to reflect pitch movement, distinction of modal functionality of sounds, sensing and precisely reproducing rhythm in the process of completing the task;

2) demonstration of such highest musical skills at work with creative task as musical thinking, sense of tone quality, understanding the logics of development of musical material, simultaneous scope of all elements of the musical language, sensitivity towards the new and the original in music and so on;

3) presence of the participant's professional musical skills, such as ability to easily combine several performing skills in the process of work on the task (singing, accompanying, directing, instrumental performance of vocal lines in parallel with accompanying), raising of artistry and absence of constraint when showing the pedagogue separate fragments of the task or the material in total;

4) degree or originality and uniqueness of the creative work, that is, presence of such indicators in the creative task as maturity of style, logics of musical form, non-standard author ideas and diversity of their texture implementation;

5) level of concert-performing skills, that is, ability to publicly present the creative work, show at the same time a bright and diverse performance that causes broad interest of audience.

\section{RESULTS AND CONCLUSIONS}

The following conclusions can be drawn:

- within two final years of education at school, profiled musical class usefully reveals that ensuring continuity and succession of learning-upbringing process and liquidating the break in becoming of the to-be music specialist (for example, in Belarus, the plan of musical education in schools of general education with musical specialisation covers grades 1-9);

- profiled musical education is the optimum base for ensuring the pre-emptive character of preuniversity musical education; 
- profiled musical training can implement variety of educational contents and form productive conditions for individual educational trajectory of the participants - the future teachersmusicians;

- profiled musical education forms background for intentional choice by the pupil of the future professional activities and facilitates the future successful socialisation.

\section{REFERENCES}

1. Гальперин, П. (1966) Психология мышления и учение о поэтапном формировании умственных действий [Psychology of Thinking and Teaching about the Formation of the Stages of Mind Processes]. П. Я. Гальперин (1966) Исследования мышиения в советской психологии [Findings about Thinking in Soviet Psychology]: сб. ст. / под ред. Е. В. Шорохова. Москва, с. 259-276 (in Russian).

2. Гребенюк, О. (2000) Основы педагогики индивидуальности: учеб. пособие [Basis of the Individuality Pedagogy]. / (Ред.) О. С. Гребенюк, Т. Б. Гребенюк. Калининград: Калининградский государственный университет, 572 с. (in Russian).

3. Гончарова, Е. (2007) Развитие творческой индивидуальности школьников в условиях профильного музыкально-педагогического обучения [The Development of the Students' Creative Individualities in Conditions of Profiled Musical Education]. Минск: Адукацыя і выхаванне, 416 c. (in Russian).

4. Коменский, Я. (1939) Избранные педагогические сочинения в 2 томах [Collected Articles of Pedagogy in 2 Volumes], Том 1. Москва: Учпедгиз, 320 с. (in Russian).

5. Паздников, М. (2004) Лицейский класс: опыт и перспективы развития [Lyceum Class: Experience and Perspectives]. In: Музыч. і тэатрал. мастацтва: праблемы выкладання, № 1, с. 3-6 (in Russian).

6. Паздников, М. (2008) Музыка для каждого из нас [Music for each of us]. In: Myзыч. i тэатрал. мастацтва: праблемы выкладання, № 3, с. 13-15 (in Russian).

7. Рыжаков, М. (2003) Профильное обучение в зарубежных странах [Profiled Teaching Abroad]. In: Профильная школа [Profiled School], № 1, с. 49-56 (in Russian).

8. Унт, И. (1990) Индивидуализация и дифференциация обучения [Individualisation and Differentiation of Teaching]. Москва: Педагогика, 188 с. (in Russian).

9. Хуторской, А. (2005) Методика личностно-ориентированного обучения: как обучать всех поразному?: пособие для учителя [Methodology of Personality Oriented Teaching: How to Teach Everybody Differently]. Москва: ВЛАДОС-ПРЕСС, 383 с. (in Russian).

Dean of Musical-Pedagogical Faculty Паздников Михаил Александрович

Maxim Tank Belarus State Pedagogical University

Address: Л. Беды, дом 8, квартира 75, Минск, 220040, Belarus

Phone: 200-13-31, 200-56-10 (work), 202-09-80 (home)

E-mail: egont@tut.by

Senior Lecturer of Pianoforte Department, Musical-Pedagogical Faculty Гончарова Евгения Петровна Maxim Tank Belarus State Pedagogical University

Address: проспект Победителей, дом 43, корп. 2, кв. 45, Минск, 220035, Belarus

Phone: 200-56-10 (work), 203-17-86 (home)

E-mail: egont@tut.by 